REGARDS

SUR LEECONOMIE ALLEMANDE

BULLETIN ECONOMIQUE DU CRAC

\section{Regards sur l'économie allemande}

Bulletin économique du CIRAC

$76 \mid 2006$

Varia

\title{
Vulgarisation économique
}

HAX Herbert, Unternehmen und Unternehmer in der Marktwirtschaft

\section{OpenEdition}

\section{Journals}

Édition électronique

URL : http://journals.openedition.org/rea/485

DOI : $10.4000 /$ rea.485

ISBN : 978-2-8218-0848-5

ISSN : 1965-0787

\section{Éditeur}

CIRAC

Édition imprimée

Date de publication : 1 mai 2006

ISSN : 1156-8992

Référence électronique

"Vulgarisation économique », Regards sur l'économie allemande [En ligne], 76 | mai 2006, document 10, mis en ligne le 05 juin 2008, consulté le 22 septembre 2020. URL : http://journals.openedition.org/rea/ 485 ; DOI : https://doi.org/10.4000/rea.485

Ce document a été généré automatiquement le 22 septembre 2020

(c) CIRAC 


\section{Vulgarisation économique}

HAX Herbert, Unternehmen und Unternehmer in der Marktwirtschaft

\section{RÉFÉRENCE}

HAX Herbert, Unternehmen und Unternehmer in der Marktwirtschaft, Kleine Reihe V\&R, Vandenhoeck \& Ruprecht, Göttingen, 2005, 189 p.

1 Dans un remarquable ouvrage de vulgarisation au format de poche, le professeur Hax, qui fut membre du Conseil des Sages et est aujourd'hui membre du Conseil scientifique $\mathrm{du}$ ministère fédéral de l'Economie, explique comment fonctionne une entreprise et quel est son rôle dans l'économie de marché. Un précieux 'manuel' de plus destiné à combler les lacunes des Allemands (voir REA 75/06) en matière de connaissances économiques. (ib) 